\title{
Risk and resilience: variations in magnesium in echinoid skeletal calcite
}

\author{
Abigail M. Smith ${ }^{1, *}$, Dana E. Clark ${ }^{1,4}$, Miles D. Lamare ${ }^{1}$, David J. Winter ${ }^{2,5}$, \\ Maria Byrne $^{3}$ \\ ${ }^{1}$ Department of Marine Science, University of Otago, PO Box 56, Dunedin 9054, New Zealand \\ ${ }^{2}$ Department of Zoology, University of Otago, PO Box 56, Dunedin 9054, New Zealand \\ ${ }^{3}$ University of Sydney, New South Wales 2006, Australia \\ ${ }^{4}$ Present address: Cawthron Institute, Private Bag 2, Nelson 7042, New Zealand \\ ${ }^{5}$ Present address: Institute of Fundamental Sciences, Massey University, Private Bag 11 222, Palmerston North 4442, New Zealand
}

\begin{abstract}
Echinoids have high-magnesium (Mg) calcite endoskeletons that may be vulnerable to $\mathrm{CO}_{2}$ driven ocean acidification. Amalgamated data for echinoid species from a range of environments and life-history stages allowed characterization of the factors controlling Mg content in their skeletons. Published measurements of $\mathrm{Mg}$ in calcite $(\mathrm{N}=261)$, supplemented by new X-ray diffractometry data $(\mathrm{N}=382)$, produced a database including 8 orders, 23 families and 73 species $(\sim 7 \%$ of the $\sim 1000$ known extant species), spanning latitudes $77^{\circ} \mathrm{S}$ to $72^{\circ} \mathrm{N}$, and including 9 skeletal elements or life stages. Mean ( \pm SD) skeletal carbonate mineralogy in the Echinoidea is $7.5 \pm 3.23$ wt $\% \mathrm{MgCO}_{3}$ in calcite (range: $1.5-16.4 \mathrm{wt} \%, \mathrm{~N}=643$ ). Variation in $\mathrm{Mg}$ within individuals was small $(\mathrm{SD}=$ 0.4-0.9 wt\% $\mathrm{MgCO}_{3}$ ). We found significant differences among skeletal elements: jaw demi-pyramids were the highest in $\mathrm{Mg}$, whereas tests, teeth and spines were intermediate in $\mathrm{Mg}$, but generally higher than larvae. Higher taxa have consistent mineralogical patterns, with orders in particular showing Mg related to first appearance in the fossil record. Latitude was a good proxy for sea-surface temperature (SST), although incorporating SST where available produced a slightly better model. Mg content varied with latitude; higher $\mathrm{Mg}$ content in warmer waters may reflect increased metabolic and growth rates. Although the skeletons of some adult urchins may be partially resistant to ocean acidification, larvae and some species may prove to be vulnerable to lowered $\mathrm{pH}$, resulting in ecosystem changes in coastal marine environments.
\end{abstract}

KEY WORDS: Carbonate mineralogy · Echinoidea • Larvae · Skeletal morphology · Urchins · Ocean acidification

\footnotetext{
*Corresponding author: abby.smith@otago.ac.nz
}

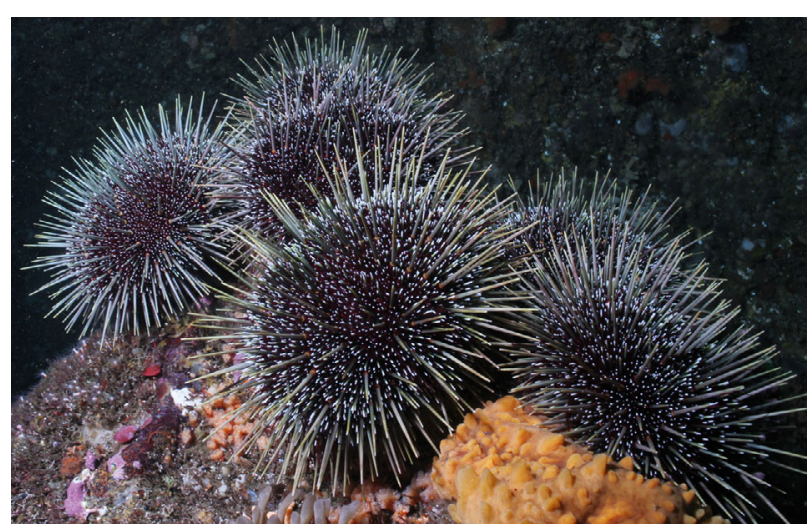

Magnesian calcite skeletons of the New Zealand endemic sea urchin Evechinus choloroticus may be vulnerable to ocean acidification.

Photo: Chris Cornelisen, Cawthron Institute

\section{INTRODUCTION}

Ocean acidification, the result of ocean uptake of increasing $p \mathrm{CO}_{2}$ (Raven et al. 2005, IPCC 2014), is decreasing the saturation state of calcium carbonate, which, in many marine invertebrates, makes the production and maintenance of calcified structures more difficult (e.g. Orr et al. 2005). The effects of ocean acidification on calcium carbonate saturation state will vary with depth and location, but general predictions are for a 2 - to 4 -fold increase in both calcite and aragonite solubility in sea surface waters this century, with the aragonite saturation horizon (below which aragonite can be expected to dissolve) reaching the surface in at least the Southern Ocean by

() The authors 2016. Open Access under Creative Commons by Attribution Licence. Use, distribution and reproduction are unrestricted. Authors and original publication must be credited. 
$\approx 2050$ (Orr et al. 2005, Fabry et al. 2008). Understanding the response of marine calcifiers, in particular their ability to make their skeletons and shells, to this major and rapid environmental change requires an understanding of skeletal carbonate mineralogy across a range of phyla and at various life-history stages.

Among these major marine calcifiers are those in the phylum Echinodermata, with approximately 7000 known extant species and 13000 extinct species, and including the Class Echinoidea (sea urchins) with about 1000 known extant species distributed in the world's oceans (Kroh \& Mooi 2011). Echinoids are ecologically important marine invertebrates and are considered to be the most important group of consumers living in shallow water (Steneck 2013). Larval, juvenile and adult echinoids have an endoskeleton of calcite $\left(\mathrm{CaCO}_{3}\right)$ produced by the mesoderm and usually covered by the epidermis, with the exception of the spines of urchins in the order Cidaroida (Dubois 2014). The teeth are also directly exposed to surrounding sea water and may contain the highest levels of magnesium (Mg) (Wang et al. 1997). The skeleton is laid down as stereom, in a 3dimensional rhombohedral mesh-like calcite lattice (with more or less Mg substitution) with individual elements being crystalline, a skeletal form unique to the Echinodermata that has its maximum development in the Echinoidea (Smith 1980, Dubois \& Chen 1989, Cavey \& Märkel 1994). Production, growth and maintenance of this mesodermal skeleton is the result of intricate and detailed biochemical pathways (Wilt 1999, Matranga et al. 2013). Calcified skeletal elements of adult echinoids include test plates, jaw components (including teeth and pyramids) and spines, both primary and secondary. The feeding echinopluteus larvae of most echinoids have a basketshaped endoskeleton supporting the body and arm rods that support the larval arms (Emlet 1988, Kinjo et al. 2006), which can be simple or fenestrated calcite rods, with the latter being more robust (Kinjo et al. 2006).

The skeletal elements of most echinoids are composed of Mg-calcite $\left(\approx 3\right.$ to $16 \mathrm{wt} \% \mathrm{MgCO}_{3}$; Chave 1952, 1954, Raup 1966), where $\mathrm{Mg}^{2+}$ is substituted for $\mathrm{Ca}^{2+}$ during calcification. The $\mathrm{Mg}$ content of Mgcalcite varies with latitude in some marine calcifiers, including echinoderms (Chave 1954, Andersson et al. 2008, McClintock et al. 2011, Lebrato et al. 2013). This trend has been attributed to differences in growth rate, carbonate saturation state and sea temperature (e.g. Mackenzie et al. 1983, Andersson et al. 2008, Hermans et al. 2010), all of which may be related.
Although the skeleton of echinoderms is calcitic, its solubility is closer to that of aragonite than pure calcite (Dubois 2014). The solubility of Mg-calcite increases with increasing $\mathrm{Mg}$ content, with calcite containing more than approximately $12 \mathrm{wt} \% \mathrm{MgCO}_{3}$ being more soluble than aragonite (Walter \& Morse 1984, Bischoff et al. 1987, Morse et al. 2006, Andersson et al. 2008). Given the high $\mathrm{Mg}^{2+}$ content of the sea urchin skeleton, the high solubility of the mineral form (Andersson et al. 2008) and the dominance of skeleton in the body wall, sea urchins are likely to be particularly vulnerable to the effects of ocean acidification. This is especially so for species in highlatitude and deep-sea environments because they already inhabit seawater that is only slightly supersaturated with respect to the carbonate phase they secrete (Andersson et al. 2008, but see Dubois 2014). As ocean $\mathrm{pH}$ progressively declines, high-latitude calcifiers are increasingly vulnerable as concurrent ocean warming will likely prevent them moving toward the lower latitudes. Marine calcifiers that deposit stable carbonate minerals such as calcite and low-Mg calcite may become increasingly dominant (Andersson et al. 2008); this also applies to taxa (e.g. sea stars) that are less calcified. Here we investigated factors that may influence skeletal carbonate mineralogy, including water temperature, water chemistry, phylogeny and natural genotypic variation.

We examined the skeletal mineralogy of sea urchins from a broad range of latitudes, from $77^{\circ} \mathrm{S}$ to $72^{\circ} \mathrm{N}$. In a comprehensive literature review and incorporating new data from the Northern and Southern Hemisphere, we collated the mineralogy of 73 echinoid species in 23 of the 50 currently recognized echinoid families (Smith \& Kroh 2011). Previous sampling efforts had been concentrated in the Northern Hemisphere, and we address this gap by generating data for specimens from the Southern Hemisphere. In addition, while a number of mineralogical studies have been published on echinoids (Clarke \& Wheeler 1922, Chave 1954, Pilkey \& Hower 1960, Raup 1966, Weber 1969, Sumich \& McCauley 1972, Bischoff et al. 1983, McClintock et al. 2011), lack of replication reported means the variability in the measurements with and between individuals cannot be assessed. For more than half of the species studied (58\%), apparently only 1 specimen was examined. For 4 species, we determined the mineralogy within individuals and among multiple individuals. We assimilated data from body skeletal elements for species from a range of environments and life-history stages, to characterize their mineralogy and evaluate the factors controlling Mg content in their skeletons. 


\section{METHODS}

A comprehensive literature review showed that 56 species (261 measurements) from (mostly) the Northern Hemisphere have had mineralogy measured and reported (Table S1 in Supplement 1 at www.intres.com/articles/suppl/m561p001_supp1.pdf); where units varied, they were standardised to $\mathrm{wt} \% \mathrm{MgCO}_{3}$. Most measurements were of test plates $(\mathrm{N}=135)$, but spines $(\mathrm{N}=79)$ and mouthparts $(\mathrm{N}=47)$ were sometimes measured. Very few measurements were replicated within an individual or in more than 1 specimen within a species or population. Only 48 measurements existed for Southern Hemisphere specimens, while there were no published measurements, worldwide, of the mineralogy of juveniles or larvae.

To address gaps in the data from the literature, adult and (where possible) juvenile specimens of echinoid species were collected in New Zealand, Australia, Antarctica and some tropical Pacific islands for this study, as well as additional specimens for the Northern Hemisphere (Table S2 in Supplement 1). Tests of juveniles and adults were bleached in $5 \% \mathrm{NaOCl}$, serially rinsed and dried, and then subsectioned for X-ray diffractometry. In total, we examined 382 specimens from 24 species, including test plates $(\mathrm{N}=112)$, primary and secondary spines ( $\mathrm{N}=81$ and 40 , respectively), demi-pyramids $(\mathrm{N}=70)$ and teeth $(\mathrm{N}=53)$, as well as juveniles $(\mathrm{N}=9)$.

Gametes of 4 species (Arachnoides placenta, Evechinus chloroticus, Pseudechinus huttoni, Tripneustes gratilla) were obtained from adult sea urchins by inducing spawning with an inter-coelomic injection of $0.5 \mathrm{M} \mathrm{KCl}$, and eggs were fertilized by adding several drops of dilute sperm. Larvae were cultured in 201 buckets filled with $1 \mu \mathrm{m}$ filtered seawater until they reached the prism or early pluteus stage, collected and bleached to remove organic material. Sixteen samples, each containing at least 1000 individual larval skeletons, were then analysed using X-ray diffractometry.

For X-ray diffractometry, approximately $0.5 \mathrm{~g}$ of each sample was placed in a clean mortar, with $0.1 \mathrm{~g}$ of analytical-grade halite $(\mathrm{NaCl})$ as an internal standard, and ground to a fine powder until it was consistent in colour and texture. A small amount of $95 \%$ ethanol was added to make a slurry which was smeared uniformly on a glass slide and left to air dry. Each sample was scanned by a Phillips X-Ray diffractometer (XRD) between $26^{\circ}$ and $33^{\circ} 2 \theta$. There was 1 count per degree, and the count time was $1 \mathrm{~s}$. Calcite peak position was corrected based on the in- ternal standard halite peak, and then a machinespecific calibration for determining $\mathrm{Mg}$ content was applied: $y=30 x-882$, where $y=\mathrm{wt} \% \mathrm{MgCO}_{3}$ in calcite and $x=$ calcite peak position in ${ }^{\circ} 2 \theta$ (after Gray $\&$ Smith 2004).

\section{Phylogenetic and environmental mixed models}

We fitted generalised linear mixed models (GLMMs) to the combined dataset using the R (R Development Core Team 2015) package MCMCglmm (Hadfield 2010). Because our observations are collected from an evolutionary diverse range of specimens, we first investigated whether our data contain any phylogenetic signal. We fitted 3 models to data from those specimens $(\mathrm{N}=327)$ that could be placed in the phylogenetic tree reported by Smith $A B$ et al. (2006). In each model, $\mathrm{wt} \% \mathrm{MgCO}_{3}$ in calcite was the response variable and 'absolute latitude' (i.e. degrees from the equator) and skeletal element were treated as fixed predictor variables. The models differed in which random variables were included; a full model containing effects for both genus and phylogenetic relationships among genera was compared to models with only phylogeny or genus included as random variables.

As described in the 'Results' section, we found only weak evidence for a phylogenetic signal in our data. For this reason, we investigated variation in mineralogy by latitude and among skeletal elements in our complete dataset (including those species that could not be placed in our phylogeny). In this case we fitted 2 models, each with $\mathrm{wt} \% \mathrm{MgCO}_{3}$ in calcite as a response variable and genus as a random variable. We compared a full model with fixed effects for absolute latitude and body part with a model containing only a latitude effect.

Finally, we tested the effectiveness of absolute latitude as a proxy for seawater temperature by analysing a subset of observations $(\mathrm{N}=386)$ from locations for which we could obtain an estimate of mean sea surface temperature (SST). For this subset of the data, we again compared 2 models, each with a random effect for genus and a fixed effect for body part. In the first model, we used SST as a fixed predictor variable; absolute latitude was used in the second.

MCMCglmm fits models via Markov chain Monte Carlo (MCMC). Before fitting models, we ran a number of preliminary analyses and found that running MCMCs for 200000 generations and sampling every $150^{\text {th }}$ iteration reliably produced consistent estimates 
with little evidence of autocorrelation. We used these parameters to fit all models described above. We chose the best fitting model using the deviance information criterion (DIC), with the lowest scoring model considered the best fit (Lunn et al. 2000). A complete record of steps used to fit and examine these models is provided in Supplement 2 at www.int-res.com/ articles/suppl/m561p001_supp2.pdf.

\section{RESULTS}

In total, we compiled 643 measurements of echinoid mineralogy, encompassing 8 orders, 23 families and 73 species (Tables 1 \& 2), and spanning latitudes from $77^{\circ} \mathrm{S}$ to $72^{\circ} \mathrm{N}$ (Fig. 1). Nine skeletal elements or life stages were represented. Taken as a group, the mean \pm SD skeletal carbonate mineralogy for the Echinoidea was $7.5 \pm 3.23 \mathrm{wt} \% \mathrm{MgCO}_{3}$ in $100 \%$ calcite (range: $1.5-16.4 \mathrm{wt} \%, \mathrm{~N}=643$ ). The raw data results for this study, along with the recalculations from published literature, are available in Supplement 1.

Variations in $\mathrm{MgCO}_{3}$ content in calcite can be ascribed to phylogenetic position, environment (e.g. temperature) and skeletal element or life stage (mouthparts, spines, test, larval skeletons), and we describe the relationships of these variables to our data below.

\section{Phylogenetic influence on echinoid mineralogy}

We investigated influences on mineralogy using a series of GLMMs. We first considered the possibility that our mineralogical data contain a phylogenetic signal (Table 2). The best fitting model in this analysis contains an effect for phylogeny. However, the phylogeny used in this model is only resolved to the genus level, meaning there are multiple observations for each tip in the tree. Thus, in addition to capturing phylogenetic relationships among genera, the phylogenetic effect in this model accounts for the fact our observations come from many discrete genera. When compared to models that contain a categorical effect for genus, the phylogenetic model provides only a marginal increase in fit $(\triangle \mathrm{DIC}<1)$, demonstrating that relationships among genera explain only a small proportion of the variance in our data.

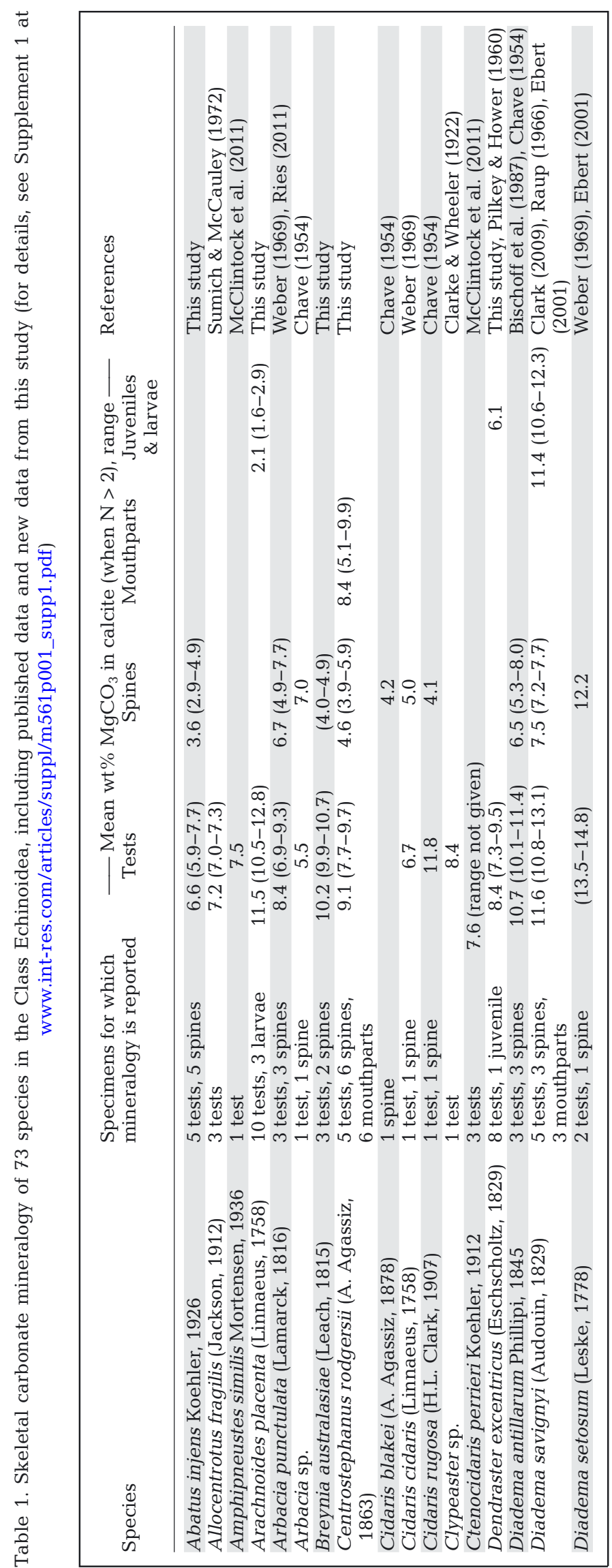




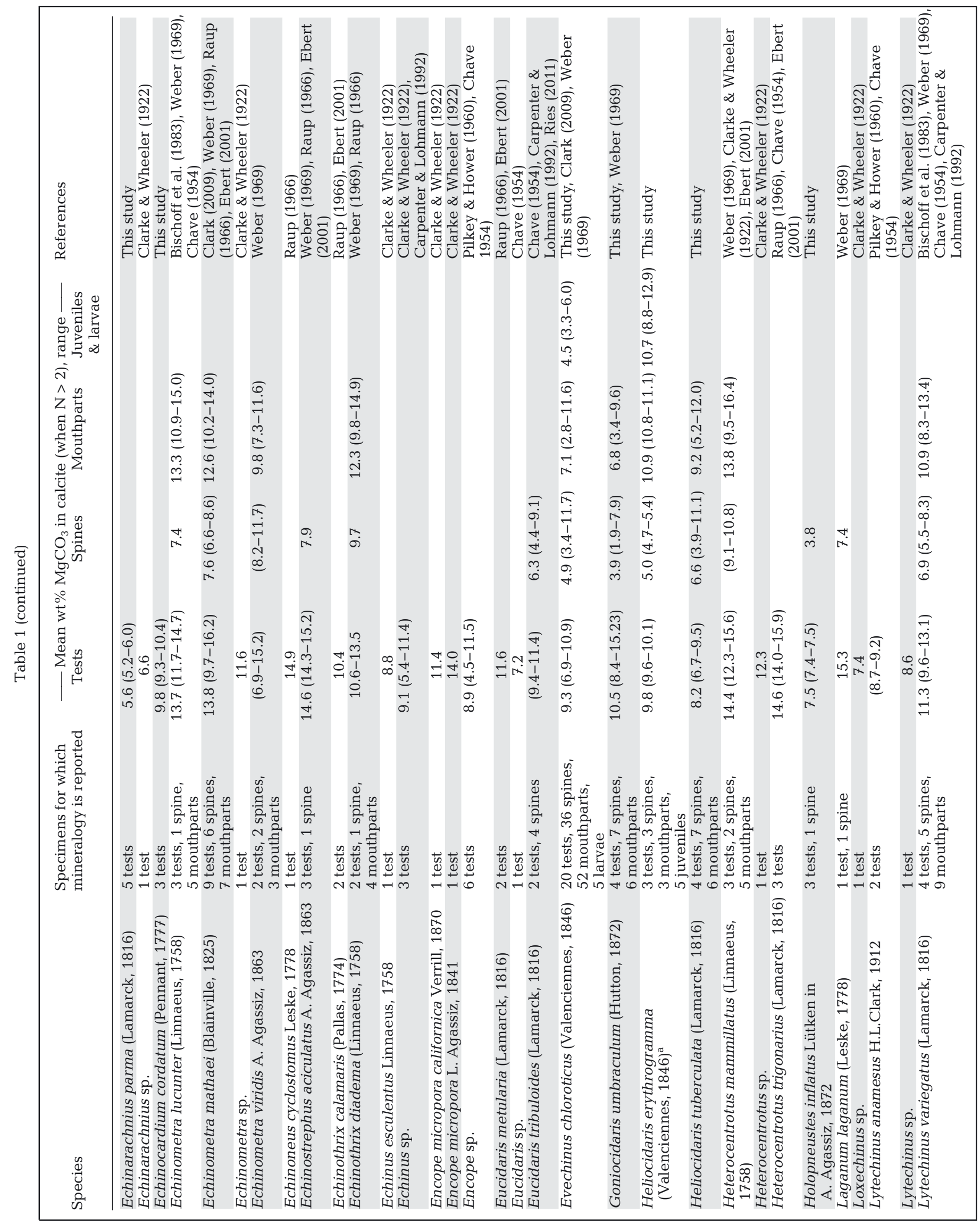




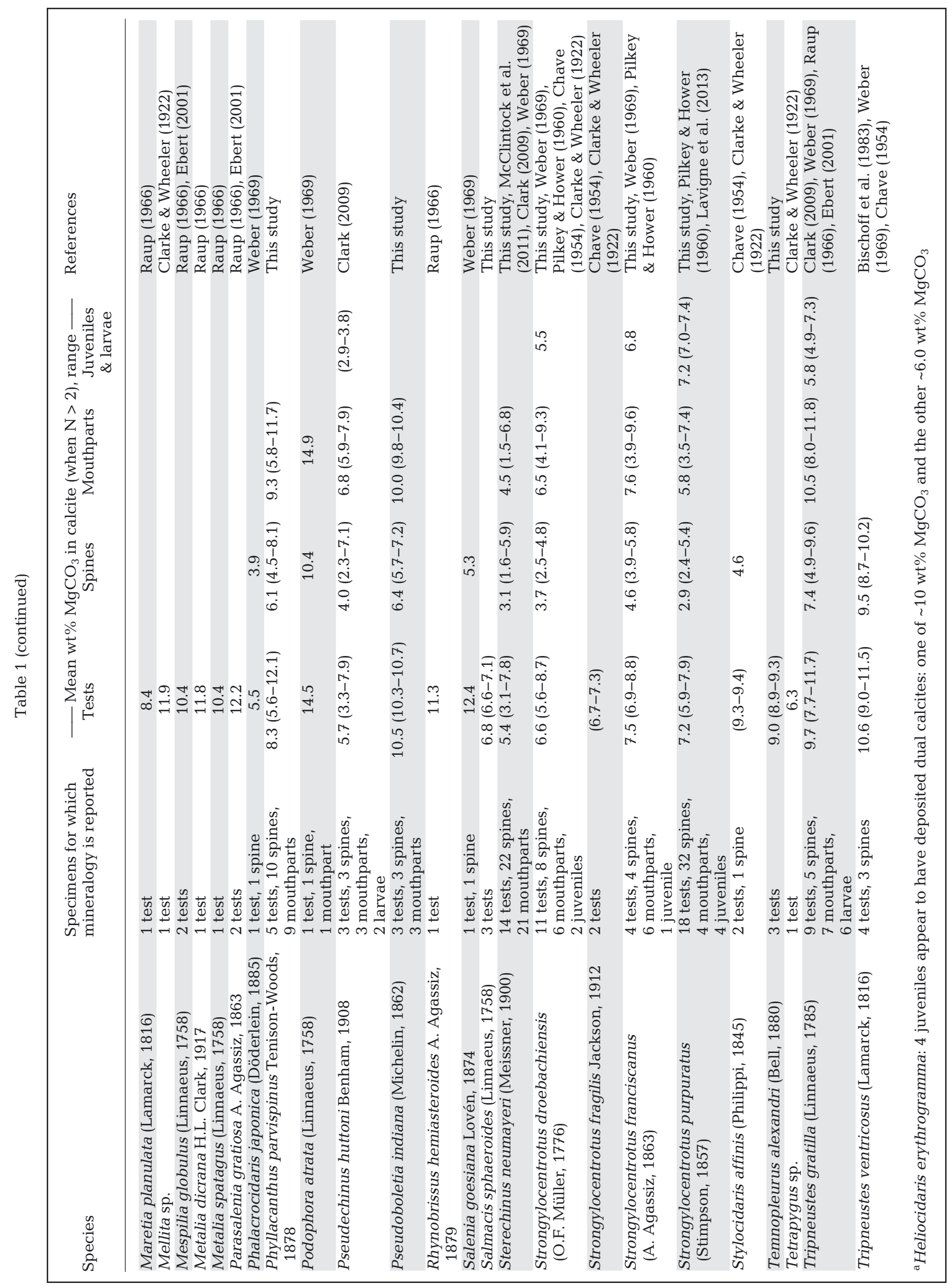




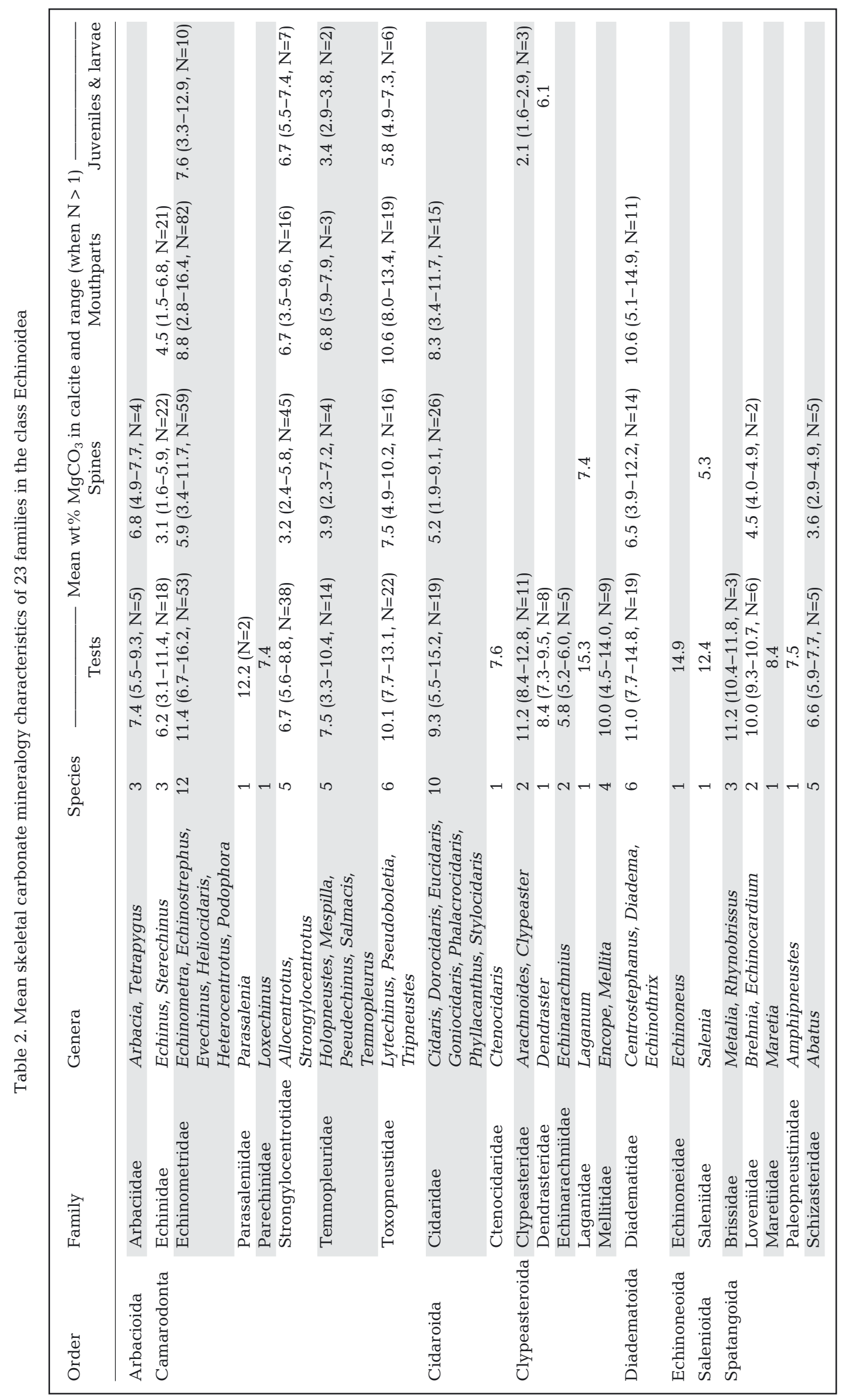




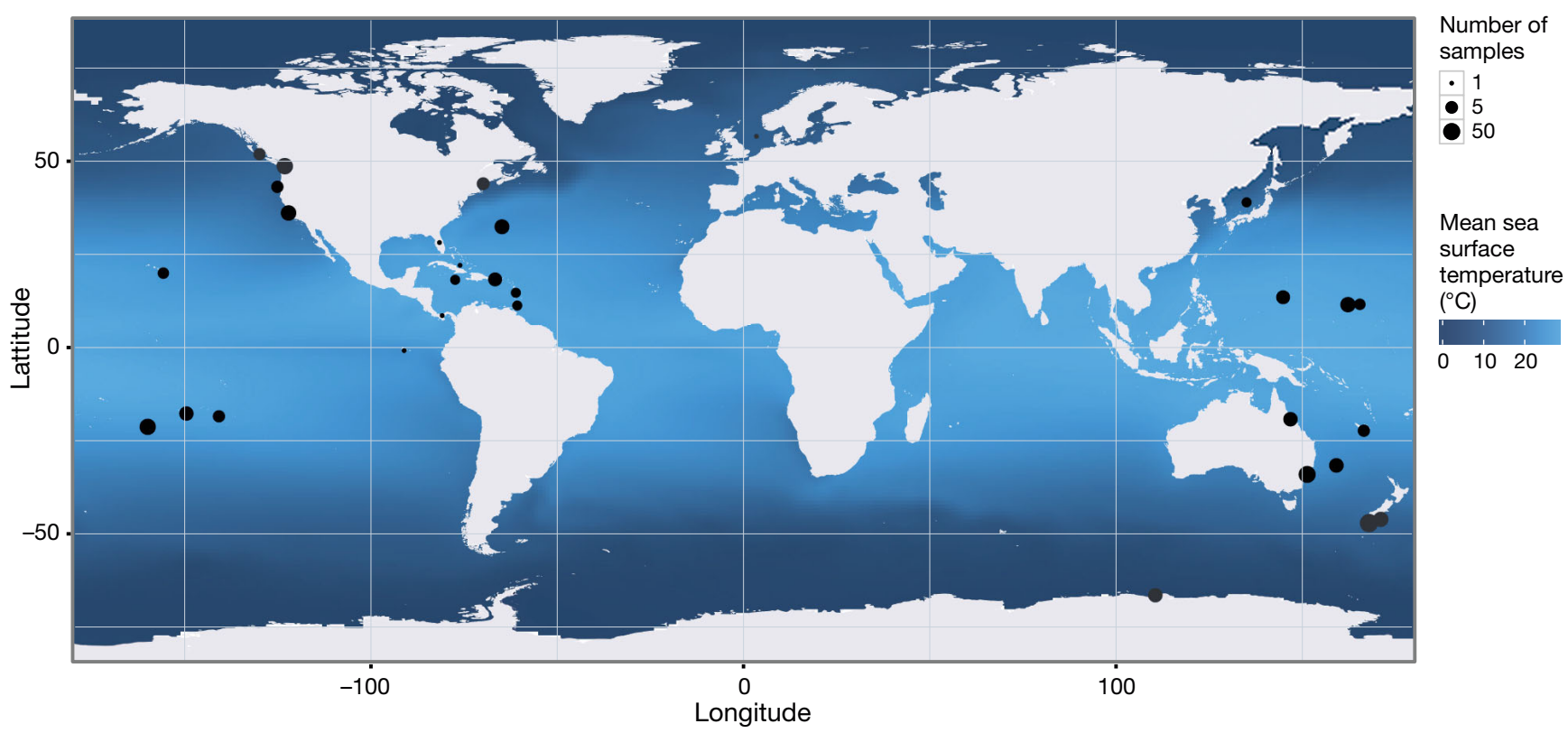

Fig. 1. Global distribution of echinoid specimens for which carbonate mineralogy has been measured (of the 643 measurements compiled in the database, 392 had adequate location data)

\section{Environmental patterns of echinoid mineralogy}

Given the relatively weak phylogenetic signal in our data, we chose to investigate ontological and environmental effects on mineralogy using the complete data set, including species that could not be placed on our phylogeny (Supplement 2). These models show significant and large effects on magnesium content of both distance from equator and the skeletal element from which measurements were taken. A model that contains effects for both of these variables fits the data substantially better than one that includes a latitude effect alone ( $\Delta$ DIC $>500$ ). Importantly, the inclusion of skeletal elements in this model alters our estimate of the effect of distance from the equator on $\mathrm{Mg}$ content. Although there is a significant effect for latitude in both models, the effect is smaller in the full model (point estimate $=$ -0.64 percentage points per degree of latitude, $95 \%$ credible interval $=-0.085$ to -0.045 ) than one that ignores the skeletal element from which measurements were taken (point estimate $=-0.09,95 \%$ credible interval $=-0.114$ to -0.061 ).

The effect of latitude described above presumably arises as a result of sea water temperature decreasing as latitude increases. We were able to obtain estimates of recent mean SST for a subset of the locations from which our data are sourced. Most new samples are from very shallow water, but depth information is seldom available in published data; in general, water depth is likely to be shallow enough for SST to be a reasonable approximation of ambient temperature. For this subset of the data, a model that uses SST to predict Mg content produces a better fit than a model using only absolute latitude (Supplement 2).

\section{Variation within individual echinoids}

Mineralogy varied systematically within an individual sea urchin. Indeed, it matters very much both what life stage and what skeletal element has been measured (Fig. 2). For example, test plates of Tripneustes gratilla contain, on average, about $9.6 \mathrm{wt} \%$ $\mathrm{MgCO}_{3}(\mathrm{~N}=5)$. Small calcareous mouthparts (rotula, pyramid, and epiphysis) of this species tend to contain more $\mathrm{Mg}$ (10.3 to $12.1 \mathrm{wt} \% \mathrm{MgCO}_{3}$ ), while the spines and teeth contain less ( 6.3 to $8.6 \mathrm{wt} \% \mathrm{MgCO}_{3}$ ). In the few echinoid species where such details are reported, the trend is similar (Table 1). Among all species in the database, the epiphysis is the highest in $\mathrm{Mg}$ (mean $\left.=12.3 \mathrm{wt} \% \mathrm{MgCO}_{3}, \mathrm{~N}=11\right)$, followed by the rotula (11.4 $\mathrm{wt} \% \mathrm{MgCO}_{3}, \mathrm{~N}=9$ ) and demipyramid (9.5 wt $\% \mathrm{MgCO}_{3}, \mathrm{~N}=83$ ). Tests (9.3 wt\% $\mathrm{MgCO}_{3}, \mathrm{~N}=317$ ) and teeth (5.7 wt $\% \mathrm{MgCO}_{3}, \mathrm{~N}=66$ ) are intermediate in $\mathrm{Mg}$ content, as are spines (5.0 wt $\% \mathrm{MgCO}_{3}, \mathrm{~N}=200$ ), although secondary spines are generally lower than primary spines (Table 3 ). Adult skeletal elements are generally higher in $\mathrm{Mg}$ 


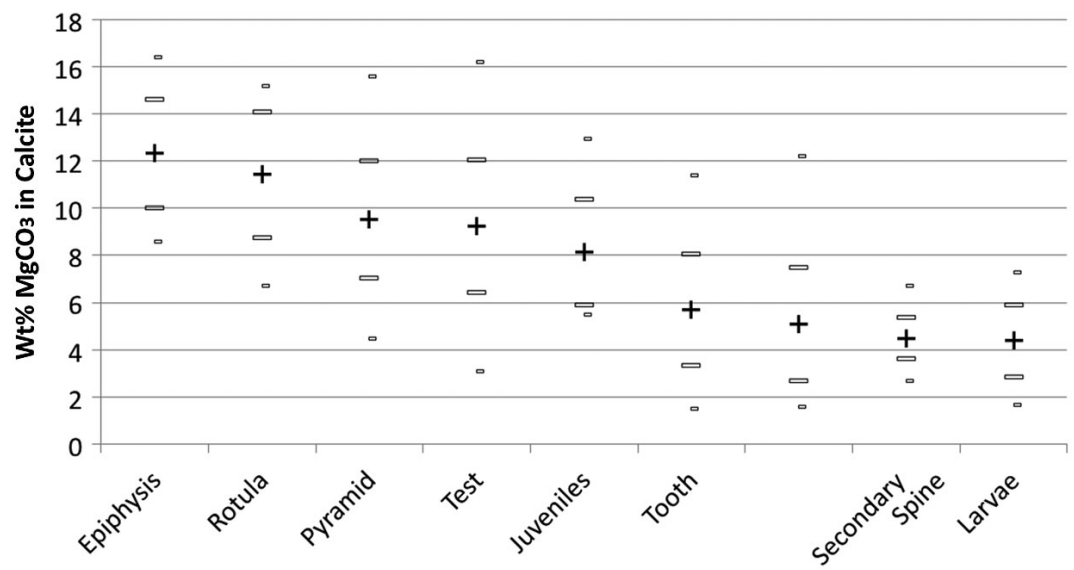

Fig. 2. Ranges of Mg in calcite among different life stages and skeletal elements in the class Echinoidea. Crosses are means, lines are $\pm 1 \mathrm{SD}$, dots are range

than larvae (4.4 wt $\left.\% \mathrm{MgCO}_{3}, \mathrm{~N}=16\right)$. There is very little apparent change in mineralogy of tests from the juvenile stage $\left(8.2 \mathrm{wt} \% \mathrm{MgCO}_{3}, \mathrm{~N}=13\right.$ ) onwards (adult tests $=9.3 \mathrm{wt} \% \mathrm{MgCO}_{3}, \mathrm{~N}=317$ ).

$\mathrm{Mg}$ content within skeletal elements in the same individual is fairly consistent, at least in Evechinus choloroticus from Stewart Island, southern New Zealand. In 1 individual from this species, 10 measurements were made on each of the major skeletal elements. The range of $\mathrm{Mg}$ in calcite in each set of 10 replicates varied from 1.5 to 2.7 wt $\% \mathrm{MgCO}_{3}$ (SD 0.4-0.9 wt\% $\mathrm{MgCO}_{3 i}$ Table 4), less than the variation among skeletal elements and among species.

In those species where more than 1 individual has been considered, there is some broad consistency of skeletal carbonate mineralogy. For example, measurements of the tests of Tripneustes gratilla had 7.7 to $11.5 \mathrm{wt} \% \mathrm{MgCO}_{3}$ $(\mathrm{N}=11)$, whereas the test measurements in Echinometra mathaei were generally higher (13.5-16.2 wt\% $\mathrm{MgCO}_{3}, \mathrm{~N}=6$ ) and those in Sterechinus neumayeri generally lower (4.7-6.8 wt\% $\mathrm{MgCO}_{3}, \mathrm{~N}=9$ ). However, variation within species $\left(\mathrm{SD}=1.0,1.1\right.$ and $0.6 \mathrm{wt} \% \mathrm{MgCO}_{3}$, respectively, for the examples above) may be ascribable to environmental differences among populations.
Table 3. Summary statistics for Mg in calcite in different life stages and skeletal elements across the class Echinoidea

\begin{tabular}{|c|c|c|c|c|c|c|}
\hline \multirow[t]{2}{*}{ Life stage } & \multirow[t]{2}{*}{ Skeletal element } & \multicolumn{4}{|c|}{$-\mathrm{Wt} \% \mathrm{MgCO}_{3}$ in calcite -} & \multirow[t]{2}{*}{$\mathrm{N}$} \\
\hline & & Mean & Minimum & Maximum & $\mathrm{SD}$ & \\
\hline \multirow[t]{9}{*}{ Adults } & Test plates & 9.3 & 3.1 & 16.2 & 2.8 & 317 \\
\hline & Primary spines & 5.1 & 1.6 & 12.2 & 2.4 & 159 \\
\hline & Secondary spines & 4.5 & 2.7 & 6.7 & 0.9 & 41 \\
\hline & All spines & 5.0 & 1.6 & 12.2 & 2.2 & 200 \\
\hline & Epiphysis & 12.3 & 8.6 & 16.4 & 2.3 & 11 \\
\hline & Demi-pyramid & 9.5 & 4.5 & 15.6 & 2.5 & 83 \\
\hline & Tooth & 5.7 & 1.5 & 11.4 & 2.4 & 66 \\
\hline & Rotula & 11.4 & 6.7 & 15.2 & 2.7 & 9 \\
\hline & All mouthparts & 8.3 & 1.5 & 16.4 & 3.3 & 169 \\
\hline Juveniles & Whole skeleton & 8.2 & 5.5 & 12.9 & 2.2 & 13 \\
\hline Larvae & Larval skeleton & 4.4 & 1.7 & 7.3 & 1.5 & 16 \\
\hline \multicolumn{2}{|c|}{ All life stages and elements } & 7.5 & 1.5 & 16.4 & 3.3 & 643 \\
\hline
\end{tabular}

Table 4. Variation in Mg in skeletal carbonate within a single individual of Evechinus chloroticus from Stewart Island, New Zealand

\begin{tabular}{|lcccccc|}
\hline Skeletal element & N & Mean & Min & Max & Range & SD \\
\hline Test & 10 & 9.3 & 7.8 & 10.4 & 2.7 & 0.88 \\
Primary spine & 10 & 4.3 & 3.4 & 4.9 & 1.5 & 0.40 \\
Secondary spine & 10 & 5.1 & 4.6 & 6.7 & 2.1 & 0.60 \\
Demi-pyramid & 10 & 10.1 & 8.8 & 11.5 & 2.7 & 0.66 \\
Tooth & 10 & 4.5 & 2.8 & 5.3 & 2.5 & 0.70 \\
\hline
\end{tabular}

\section{DISCUSSION}

There is still much to learn about $\mathrm{Mg}$ in echinoid skeletons. In this study, data were collated on the mineralogy of 73 echinoid species in 23 families. While these data provide a substantial addition to our understanding of echinoid mineralogy, 73 species represents only $\sim 7 \%$ of living echinoid species, and there are no data for many orders (e.g. Pedinoida, Holectypoida, Holasteroida), especially the diverse and fragile deep-sea order Echinothurioida.

\section{Variation within individuals}

Echinoids are unlike the many taxa where individual mineralogy does not appear to vary systematically (see, e.g. Smith et al. 2013); in fact, different skeletal elements may vary considerably in composition within a single individual. In a general way, Mg content in echinoid skeletal components increases with distance from the surrounding sea water. Lowest $\mathrm{Mg}$ content is found in the 
spines, with more in the test and teeth, and the highest $\mathrm{Mg}$ content in the internal feeding structures of Aristotle's lantern. The lower-Mg skeletal elements are more chemically stable and potentially more resistant to dissolution than those with $\mathrm{MgCO}_{3}$ greater than about $12 \mathrm{wt} \%$. Since the test, teeth and spines extend into the water column, they may benefit from the lower solubility associated with lower $\mathrm{Mg}$ in calcite. The spines of the order Cidaroida also lack a protective ectodermal cover, but the spines are resilient to acidification due to a specialised outer layer of polycrystalline calcite called the cortex (Dery et al. 2014, Dubois 2014). These are the same elements that may become more at risk of dissolution than other skeletal elements as pH falls in the surface oceans (e.g. Raven et al. 2005). Ma et al. (2009) showed that $\mathrm{Mg}$ content in the grinding tooth increases towards the tip, and they theorised that increasing $\mathrm{Mg}$ increases the mechanical hardness of the calcite. If this is so, it may provide a further explanation for variations in $\mathrm{Mg}$ content in calcite produced by a single individual, navigating the tradeoffs between resistance to chemical dissolution and mechanical strength. While there may be variation of Mg within a single skeletal element, as the entire element was prepared for analysis, we would not be able to discern any local variation. Others have elucidated the variations in $\mathrm{Mg}$ associated with the cutting edge of urchin teeth (Killian et al. 2011), observing that the strongest parts of the teeth are enriched in $\mathrm{Mg}$ relative to the rest of the tip.

Adult and juvenile skeletal elements are generally higher in Mg than larvae of the same species. At least some skeletal elements show variation in mineralogy within the element. It is possible that larvae, being small and perhaps vulnerable to dissolution in the water column, require their skeletons to be formed of less soluble low-Mg calcite. Even though they pro- duce only small amounts of calcite, it does form a relatively large part of their body weight (17 to $67 \%$ of dry weight, Clark et al. 2009, Gonzalez-Bernat et al. 2012). However, Dubois (2014) stressed that the larval skeleton remains protected from the direct effects of lower-saturation water by mesoderm cells, and a recent meta-analysis indicated that the vulnerability of the larval skeleton is largely due to energetic constraints (Byrne et al. 2013, see also Stumpp et al. 2012). Tropical echinoplutei are comparatively more sensitive to ocean acidification (Byrne et al. 2013), possibly due to a higher Mg content of their skeleton. If the energetic cost of adding $\mathrm{Mg}$ to calcite reduces their other functions, perhaps they precipitate the most stable mineral they can.

It is also important to note that the inclusion of skeletal element and life stage in our GLMMs altered our estimate of effect of latitude on $\mathrm{Mg}$ content. In addition, incorporation of SST data produced a slightly better model to predict Mg content. In cases where species live at similar latitudes but with different influences of boundary currents and upwelling, these contrasting thermal regimes as well as carbonate mineral saturation states (Gruber et al. 2012) may prove to be important. It is therefore crucial that this source of variation is included in future synthesis studies and that studies report local SST so that it may be included in future meta-analyses.

\section{Phylogenetic influences on echinoid mineralogy}

Phylogenetic patterns are common in skeletal carbonate mineralogy, as in the sponges (Smith et al. 2013) and bryozoans (Smith AM et al. 2006). Here among the urchins, mineralogy within echinoid orders is relatively consistent (Table 5). For example, the standard deviations of 1.5 to $3.6 \%$ within the 8

Table 5. Comparison of the observed mineralogy of modern specimens in echinoid orders with the seawater chemistry of the time of their first appearance in the fossil record. First fossil appearance data from Smith AB et al. (2006) and Fossilworks.org; past seawater data from Ries (2004)

\begin{tabular}{|c|c|c|c|c|c|c|c|c|c|c|}
\hline \multirow{3}{*}{ Order } & \multicolumn{4}{|c|}{ First appearance data from fossil record- } & \multicolumn{6}{|c|}{ — Known mineralogy of modern specimens - } \\
\hline & \multirow{2}{*}{$\begin{array}{l}\text { Date of } \\
\text { first fossils } \\
\text { (Mya) }\end{array}$} & \multirow{2}{*}{ Period } & \multirow{2}{*}{$\begin{array}{c}\text { Past } \\
\text { seawater } \\
\text { Mg:Ca ratio }\end{array}$} & \multirow{2}{*}{$\begin{array}{l}\text { Past } \\
\text { carbonate } \\
\text { sea state }\end{array}$} & \multicolumn{3}{|c|}{ Test plates } & \multicolumn{3}{|c|}{ Spines } \\
\hline & & & & & $\mathrm{N}$ & Mean & $\mathrm{SD}$ & $\mathrm{N}$ & Mean & $\mathrm{SD}$ \\
\hline Clypeasteroida & $100-105$ & Albian, Early Cretaceous & 1 & Calcite II & 35 & 8.4 & 2.9 & 1 & 7.4 & \\
\hline Camarodonta & $115-120$ & Aptian, Early Cretaceous & 0.8 & Calcite II & 149 & 8.3 & 3.6 & 115 & 6.1 & 1.2 \\
\hline Echinoneoida & $160-165$ & Middle-Late Jurassic & 2 & Transition & 1 & 14.9 & & 1 & & \\
\hline Spatangoida & $160-165$ & Middle-Late Jurassic & 2.1 & Transition & 16 & 8.4 & 2.4 & 7 & 8.0 & 2.5 \\
\hline Arbacioida & $165-170$ & Middle Jurassic & 2.1 & Transition & 5 & 7.4 & 1.5 & 8 & 4.0 & 1.1 \\
\hline Salenioida & $180-185$ & Early Jurassic & 2.2 & Aragonite II & 1 & 12.4 & & 1 & 5.3 & \\
\hline Diadematoida & 190-195 & Early Jurassic & 2.4 & Aragonite II & 19 & 10.9 & 2.4 & 13 & 7.8 & 2.1 \\
\hline Cidaroida & $250-255$ & Early Triassic & 2.6 & Aragonite II & 20 & 8.9 & 2.9 & 18 & 5.9 & 1.5 \\
\hline
\end{tabular}


orders are less than the range observed among the orders (SD of global mean $=7.5 \%$ ). In most of the orders, test plates are generally intermediate in $\mathrm{Mg}$ content (with means ranging from 7.4 to $8.9 \mathrm{wt} \%$ $\mathrm{MgCO}_{3}$ ). However, the orders Diadematida, Echinoneoida and Salenioida contain on average greater than $10 \mathrm{wt} \% \mathrm{MgCO}_{3}$ in test plates, although sample size is too small for valid generalisation in the latter 2 (only 1 specimen each), and as they are largely tropical orders, there may be an effect of temperature. Mean mineralogy of spines is both lower in $\mathrm{Mg}$ and less variable in all species examined.

The echinoid order Cidaroida appeared in the fossil record for the first time in the early Triassic (Smith $\mathrm{AB}$ et al. 2006), when the Mg:Ca ratio in the global ocean was $>3$. These are the only urchins that survived the Triassic mass extinction event and are considered to be the ancestral group from which all modern Echinoidea evolved (Smith 1984). The Orders Selenioida and Diadematoida appeared in the early Jurassic (Smith AB et al. 2006; Fossilworks.org) when the $\mathrm{Mg}$ :Ca ratio was still $>2$ (a so-called aragonite sea). Over the next 50 million years, the $\mathrm{Mg}$ :Ca ratio decreased, so that by the time fossils of the orders Clypeasteroida and Camarodonta appeared in the fossil record during the Early Cretaceous, the $\mathrm{Mg}: \mathrm{Ca}$ ratio in the global ocean was about 1 (a calcite sea). Orders Echinoneoida, Spatangoida and Arbacioida appeared for the first time during the transition period in the Middle to Late Jurassic. Recent studies show that high-Mg calcite producing organisms, including echinoids, precipitate Mg in calcite proportional to the Mg:Ca ratio in seawater (Ries 2010), and it has been suggested that in the late Cretaceous, these organisms may have precipitated low-Mg calcite in response to the low $\mathrm{Mg}$ :Ca ratio present at that time. Although the relationship between seawater $\mathrm{Mg}: \mathrm{Ca}$ ratio at first appearance in the fossil record, and the overall mineralogy of modern taxa might be expected to be blurred by environmental change and evolution, nevertheless the echinoid orders show, at least in test plates, a general decrease in $\mathrm{Mg}$ content over the transition from an aragonite sea to a calcite sea (Fig. 3). The spine data show no such change; Ries (2010) also noted that the mineralogy of spines is less likely than that of test plates to reflect seawater chemistry.

\section{Environmental patterns and ocean acidification}

In our model, SST data are sufficiently similar to their proxy (absolute latitude), so that we are able to

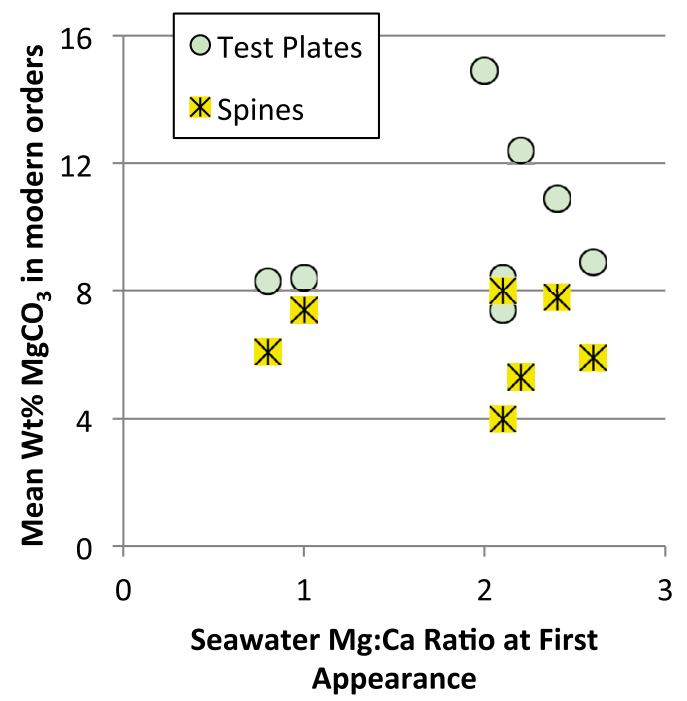

Fig. 3. Relationship between the Mg:Ca ratio in seawater at the time of first fossil appearance to $\mathrm{Mg}$ in calcite in modern echinoid orders

use published or inferred latitude to consider temperature effects on Mg incorporation (see Supplement 2). Latitude and seawater temperature are strongly related to variation in $\mathrm{Mg}$ content (independent of latitude-related phylogenetic effects), within both family and skeletal elements (Fig. 4). This parabolic relationship shows that among and within families and skeletal elements, Mg in general decreases with increasing latitude (and decreasing temperature).

Seawater temperature and $\mathrm{Mg}$ content are correlated in many echinoderms (Clarke \& Wheeler 1917, Chave 1954, Pilkey \& Hower 1960, Raup 1966, Weber 1969, Davies et al. 1972, Richter \& Bruckschen 1998, Clark 2009), although confounding factors have been noted, such as phylogenetics (Raup 1966, Davies et al. 1972), growth rate (Dodd 1967, Weber 1969), robustness (Clark 2009) and age (Davies et al. 1972, Sumich \& McCauley 1972). Our data allow some disentangling of these strands.

Among both larvae and adults, tropical species generally contain more $\mathrm{MgCO}_{3}$ than temperate species, which in turn show higher levels than those from polar regions (Fig. 4); this follows a similar pattern in skeletal robustness, where tropical echinoid adults and larvae have greater weight:volume ratio than their cold-water counterparts (Clark 2009). In tropical waters, high saturation with respect to calcium carbonate may reduce the energetic costs of calcification.

Weber (1969) suggested that this 'temperature effect' arises from higher calcification rates at warmer water temperatures and that an increase in 


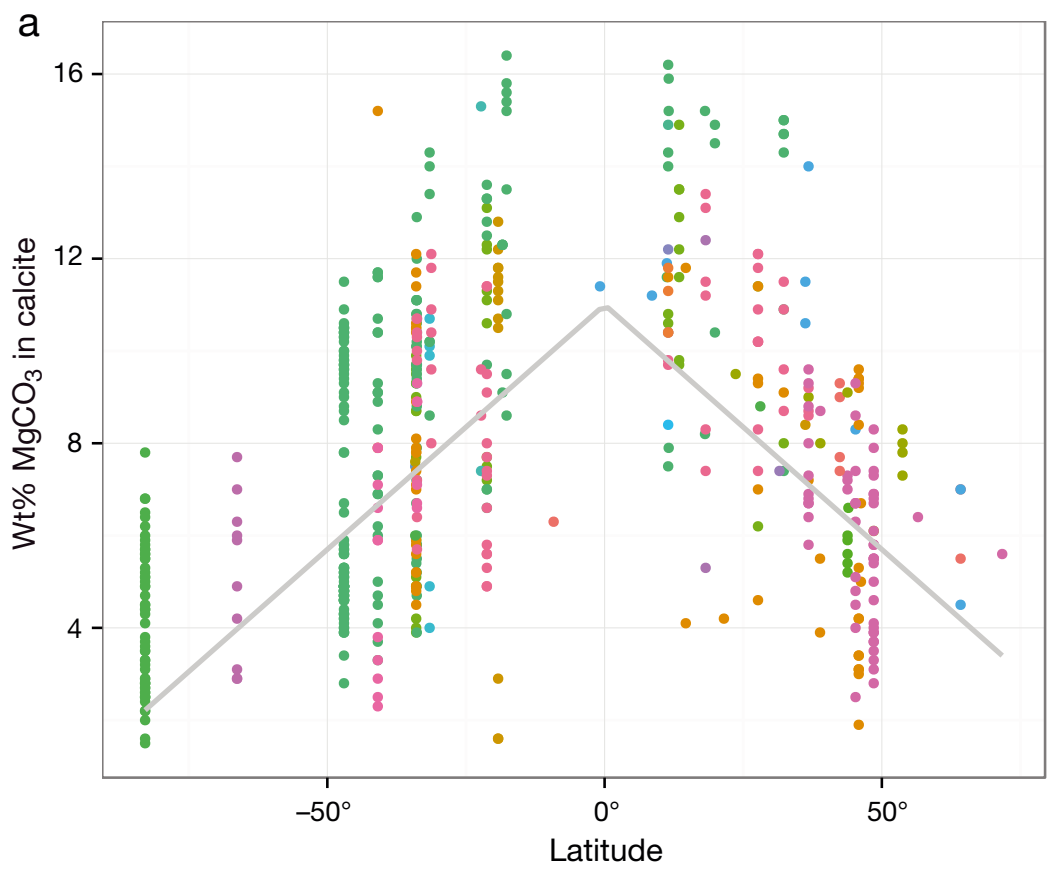

\begin{tabular}{|c|c|c|}
\hline \multicolumn{2}{|c|}{ Family } & \\
\hline Brissidae & - & Loveniidae \\
\hline Cidaridae & - & Maretiidae \\
\hline Clypeasteridae & $\bullet$ & Mellitidae \\
\hline Ctenocidaridae & - & Paleopneustinidae \\
\hline Dendrasteridae & - & Parasaleniidae \\
\hline Diadematidae & $\bullet$ & Parechinidae \\
\hline Echinarachniidae & - & Saleniidae \\
\hline Echinidae & - & Schizasteridae \\
\hline Echinometridae & - & Strongylocentrotidae \\
\hline Echinoneidae & - & Temnopleuridae \\
\hline
\end{tabular}

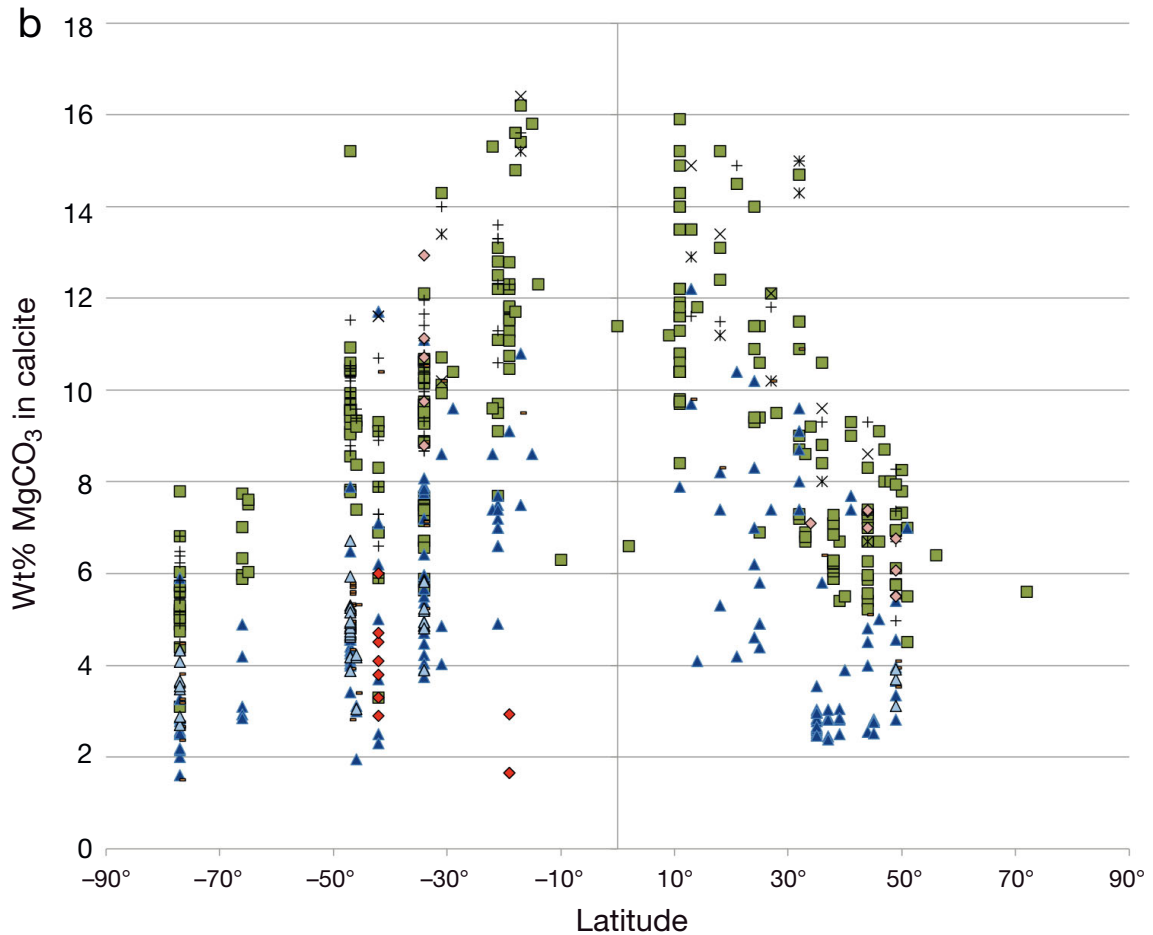

$\square$ Test $N=214$

A Primary spine $\mathrm{N}=124$

$\times$ Epiphysis $\mathrm{N}=11$

* Rotula $\mathrm{N}=9$

+ Demipyramid $\mathrm{N}=83$

- Tooth N = 65

- Larvae $N=16$

$\triangle$ Secondary spine $N=40$

$\diamond$ Juveniles $N=9$

Fig. 4. Latitudinal variation of Mg in calcite among (A) families and (B) skeletal elements in the class Echinoidea. Grey lines: trend

the rate of calcification increases the amount of magnesium captured by a crystal growing in an organic matrix. Given that the solubility product of calcite is approximately 1.3 times higher in polar temperatures $\left(\mathrm{K}_{\mathrm{sp}}\right.$ at $\left.0^{\circ} \mathrm{C} \sim 0.71 \times 10^{6}\right)$ compared with tropical sea temperatures $\left(\mathrm{K}_{\mathrm{sp}}\right.$ at $\left.30^{\circ} \mathrm{C} \sim 0.52 \times 10^{6}\right)$, the incorpo- ration of magnesium into calcite (further increasing solubility) in polar species could mean that maintaining a skeleton would just become too physiologically demanding.

Although biogenic calcite is generally less soluble than biogenic aragonite, the addition of Mg increases 
its solubility, so that the high-Mg calcite of echinoids is just as vulnerable to ocean acidification as that of their aragonitic tropical counterparts (Andersson et al. 2008). There is some suggestion that the addition of $\mathrm{Mg}$ to calcite strengthens its mechanical properties (Killian et al. 2011, Long et al. 2014, Stock 2014), but it may be that the mechanical advantages conveyed by $\mathrm{Mg}$ are be overshadowed by the chemical disadvantages.

Published models suggest that temperate and polar waters, where many echinoids are important parts of the ecosystems, may reach undersaturation first on the planet, especially in the Southern Ocean (Andersson et al. 2008). Even with the lower Mg content typical of cool-water echinoids, undersaturation in coastal waters could affect survival, calcification and especially reproductive success and settlement of larvae (Clark 2009, Sewell \& Hofmann 2011).

Calcite of tropical urchin species is typically high in $\mathrm{Mg}$, often reaching $12 \mathrm{wt} \% \mathrm{MgCO}_{3}$, the threshold above which high Mg-calcite becomes more soluble than aragonite (Bischoff et al. 1987). They too may be particularly vulnerable to the effects of ocean acidification when the lower carbonate saturation levels predicted to occur in the Southern Ocean and subArctic Pacific by 2050 and 2100, respectively (Orr et al. 2005), extend to lower latitudes.

Among the skeletal elements, those highest in $\mathrm{Mg}$ (the internal elements of Aristotle's lantern: epiphysis, rotula and pyramid) would be the most vulnerable to acidification, but they are separated from seawater by layers of tissue. In addition, sea urchins exhibit considerable capacity to adjust the acid-base balance of their coelomic fluid in response to increased acidification and thus can maintain body fluid homeostasis (Collard et al. 2014), although living with increased acidification incurs an energetic cost (Carey et al. 2016). It may be that spines, teeth and test plates, although lower in Mg and thus less soluble, will prove to be more vulnerable to dissolution effects. For the spines, this is especially the case for the growing tip (Wolfe et al. 2013). Parts of teeth that are higher in Mg may also be highly vulnerable. Very small skeletal elements that are not well protected from sea water (such as larval echinoids) would be the most vulnerable of all (Clark et al. 2009, Sewell \& Hofmann 2011). Studies on the reduction in strength caused by exposure to acidified sea water thus far have concentrated on test thickness of adults, in terms of resistance to predators crushing whole skeletons (e.g. Asnaghi et al. 2014, Byrne et al. 2014). Similar investigation of individual skeletal elements and/or juveniles is the next step.
The logical end result of either reduced calcification or post-precipitation dissolution is that skeletal elements end up thinner or lower in Mg. Decreased $\mathrm{Mg}$ in calcite may reduce solubility, but it could reduce strength as well. Consequently, mechanical attack through predation or wave energy becomes more effective at destroying or stressing the shell. If the need for sufficiently strong shells means that there is more investment in calcification, there is less energy available for reproduction or other more 'optional' activities (growth, reproduction, defense). If external sea water chemistry is reflected in intercellular $\mathrm{pH}$, mouthparts in particular could become weaker, which would make feeding less effective or remove access to some food sources. If some groups regulate their internal $\mathrm{pH}$, as may be the case with cidaroid urchins (Collard et al. 2014), they may be less vulnerable to acidification.

Alternatively, sea urchins may be able to accommodate changing sea-water chemistry by changing biomineralisation pathways (see, e.g. Findlay et al. 2009). Indeed, some skeletons vary naturally and in response to carbonate chemistry with, for example, the Mg content in Paracentrotus lividus and Arbacia lixula increased by 541 and $243 \%$, respectively, across $\mathrm{pH}$ gradients associated with $\mathrm{CO}_{2}$ seeps (Bray et al. 2014), and individuals of Eucidaris tribuloides precipitating $\mathrm{Mg}$ in calcite proportional to the $\mathrm{Mg}: \mathrm{Ca}$ ratio of seawater (Ries 2004). Vent site studies consistently show that some echinoid species are relatively resistant to high- $\mathrm{CO}_{2}$ environments (e.g. Fabricius et al. 2014, Uthicke et al. 2016), while others are not (Calosi et al. 2013). In addition, the mineralogy of the test of Tripneustes gratilla reared in ocean acidification conditions from the very early juvenile $(5 \mathrm{~mm})$ to the mature adult stage $(\sim 60 \mathrm{~mm})$ did not differ from that of urchins reared in control present-day conditions (Byrne et al. 2014).

Some species are going to be more or less vulnerable than others, related to the complex interplay of mineralogy, water temperature, size, growth investment and life history. It is not surprising that detailed studies have shown species-specific responses to the same conditions (Fabricius et al. 2014). Even if urchins are able to compensate for $\mathrm{CO}_{2}$-related stress in terms of growth and survival, they may have behavioural responses (such as reduced motility and smaller grazing haloes, Kroeker et al. 2013) to ocean acidification.

If skeletal weakness or compromised metabolism do reduce the effectiveness of echinoid settlement, feeding, survival and/or reproduction, as may happen in at least some species, then the inevitable 
effect will be to affect the balance in the many coastal ecosystems dominated and/or maintained by echinoids. These invertebrates are often critical components of the coastal ecosystems where they function as ecological engineers where low and high abundance can drive shifts in alternative stable states, from kelp forests to macroalgal free barrens habitat (Steneck 2013). Management of urchin populations world-wide has included wholesale removal to protect foliose seaweeds and over-fishing; for some high-Mg species, skeletal vulnerability to dissolution pressure adds more vulnerability to their already precarious situation.

\section{CONCLUSIONS}

Skeletal carbonate mineralogy and morphology of sea urchins vary greatly. Larvae are usually lower in Mg than adults, with both Mg content and skeletal robustness decreasing in cooler waters. Adults show a similar trend, but with the added complication that different skeletal elements within individuals also vary. Mouthparts are generally higher in $\mathrm{Mg}$ than tests, while spines and teeth have lower Mg contents. It may be that one source of this variability is the dramatic change in seawater chemistry from the Triassic to the Cretaceous, when these different orders of echinoids were evolving. While the calcite of polar species is lower in $\mathrm{Mg}$ and thus potentially less soluble than that of lower-latitude counterparts, the combination of delicate skeletal morphology and rapidly decreasing $\mathrm{pH}$ suggests that polar echinoid species may be particularly vulnerable to the effects of ocean acidification. Calcite of many tropical species is more soluble than aragonite, so that these species may be at risk if under-saturation extends to lower latitudes. Dissolution pressure and/or energetic constraints due to reduced mineral saturation could exacerbate ecological stresses in some urchin species, affecting whole coastal ecosystems.

Acknowledgements. We thank Antarctica New Zealand for their logistical support in Antarctica, and Ian Bertram and The Cook Islands Ministry of Marine Resources for assisting in research at Aitutaki. Thanks also to Richard Storey of the Cook Island Marine Research Centre, Liz Girvan at the Otago Centre for Electron Microscopy and staff at the Portobello Marine Laboratory, University of Otago. This research was supported by a University of Otago Research Grant (M.D.L.). D.E.C. was supported by a Brenda Shore Award from the Federation of Graduate Women, Otago Branch, and a University of Otago Post-Graduate Award.

\section{LITERATURE CITED}

Andersson AJ, Mackenzie FT, Bates NR (2008) Life on the margin: implications of ocean acidification on Mgcalcite, high latitude and cold-water marine calcifiers. Mar Ecol Prog Ser 373:265-273

> Asnaghi V, Magialajo L, Gattuso JP, Francour P, Privitera D, Chiantore M (2014) Effects of ocean acidification and diet on thickness and carbonate elemental composition of the test of juvenile sea urchins. Mar Environ Res 93: 78-84

Bischoff WD, Bishop FC, Mackenzie FT (1983) Biogenically produced magnesian calcite: inhomogeneities in chemical and physical properties: comparison with synthetic phases. Am Mineralogist 68:1183-1188

> Bischoff W, Mackenzie F, Bishop FC (1987) Stabilities of synthetic magnesian calcites in aqueous solution: comparison with biogenic materials. Geochim Cosmochim Acta 51:1413-1424

> Bray L, Pancucci-Papadopoulou MA, Hall-Spencer JM (2014) Sea urchin response to rising $\mathrm{pCO}_{2}$ shows ocean acidification may fundamentally alter the chemistry of marine skeletons. Mediterr Mar Sci 15:510-519

Byrne M, Lamare M, Winter D, Dworjanyn SA, Uthicke S (2013) The stunting effect of a high $\mathrm{CO}_{2}$ ocean on calcification and development in sea urchin larvae, a synthesis from the tropics to the poles. Philos Trans R Soc Lond B Biol Sci 368:20120439

Byrne M, Smith AM, West S, Collard M, Dubois P, Grabalandry A, Dworjanyn SA (2014) Warming influences $\mathrm{Mg}^{2+}$ content, while warming and acidification influence calcification and test strength of a sea urchin. Environ Sci Technol 48:12620-12627

Calosi P, Rastrick SPS, Graziano M, Thomas SC and others (2013) Distribution of sea urchins living near shallow water $\mathrm{CO}_{2}$ vents is dependent upon species acidbase and ion-regulatory abilities. Mar Pollut Bull 73: 470-484

Carey N, Harianto J, Byrne M (2016) Urchins in a high $\mathrm{CO}_{2}$ world: partitioned effects of body-size, ocean warming and acidification on metabolic rate. J Exp Biol 219: 1178-1186

> Carpenter SJ, Lohmann KC (1992) Sr/Mg ratios of modern marine calcite: empirical indicators of ocean chemistry and precipitation rate. Geochim Cosmochim Acta 56: 1837-1849

Cavey MJ, Märkel K (1994) Class Echinoidea. In: Harrison F, Chia FS (eds) Microanatomy of the invertebrates. Vol 14: Echinodermata. Alan R. Liss, New York, NY, p 345-400

> Chave KE (1952) A solid solution between calcite and dolomite. J Geol 60:190-192

> Chave KE (1954) Aspects of the biogeochemistry of magnesium 1. Calcareous marine organisms. J Geol 62:266-283

Clark DE (2009) Response of sea urchin pluteus larvae (Echinodermata: Echinoidea) to reduced seawater $\mathrm{pH}$ : a comparison among tropical, temperate and polar species. MSc thesis, University of Otago, Dunedin

> Clark D, Lamare M, Barker M (2009) Response of sea urchin pluteus larvae (Echinodermata: Echionoidea) to reduced seawater $\mathrm{pH}$ : a comparison among a tropical, temperate, and a polar species. Mar Biol 156:1125-1137

Clarke FW, Wheeler WC (1917) The inorganic constituents of marine invertebrates. US Geol Surv Prof Pap 102:1-56

Clarke FW, Wheeler WC (1922) The inorganic constituents of marine invertebrates. US Geol Surv Prof Pap 124:1-62 
Collard M, De Ridder C, David B, Dehairs F, Dubois P (2014) Could the acid-base status of Antarctic sea urchins indicate a better-than-expected resilience to near-future ocean acidification? Glob Change Biol 21:605-617

Davies TT, Crenshaw MA, Heatfield BM (1972) The effect of temperature on the chemistry and structure of echinoid spine regeneration. J Paleontol 46:874-883

> Dery A, Guibourt V, Catarino AI, Compère P, Dubois P (2014) Properties, morphogenesis and effect of acidification on spines of the cidaroid sea urchin Phyllacanthus imperialis. Invertebr Biol 133:188-199

Dodd JR (1967) Magnesium and strontium in calcareous skeletons: a review. J Paleontol 41:1313-1328

> Dubois P (2014) The skeleton of postmetamorphic echinoderms in a changing world. Biol Bull (Woods Hole) 226: 223-236

Dubois P, Chen CP (1989) Calcification in echinoderms. In: Jangoux M, Lawrence JM (eds) Echinoderm studies 3. Balkema, Rotterdam, p 109-178

Ebert TA (2001) Growth and longevity of post-settlement sea urchins. In: Lawrence JM (ed) Edible sea urchins: Biology and Ecology. Elsevier, p 79-102

Emlet RB (1988) Larval form and metamorphosis of a 'primitive' sea urchin, Eucidaris thouarsi (Echinodermata; Echionidea: Cidaroida) with implications for developmental and phylogenetic studies. Biol Bull (Woods Hole) 174:4-19

> Fabricius KE, De'ath G, Noonan S, Uthicke S (2014) Ecological effects of ocean acidification and habitat complexity on reef-associated macroinvertebrate communities. Proc R Soc Lond B Biol Sci 281:20132479

Fabry VJ, Seibel BA, Feely DA, Orr JC (2008) Impacts of ocean acidification on marine fauna and ecosystem processes. ICES J Mar Sci 65:414-432

Findlay HS, Wood H, Kendall MA, Spicer JI, Twitchett RJ, Widdicombe S (2009) Calcification, a physiological process to be considered in the context of the whole organism. Biogeosci Discuss 6:2267-2284

Gonzalez-Bernat MJ, Lamare M, Uthicke S, Myrne M (2013) Fertilisation, embryogenesis and larval development in the tropical intertidal sand dollar Arachnoides placenta in response to reduced seawater $\mathrm{pH}$. Mar Biol 160:1927-1941

Gray BE, Smith AM (2004) Mineralogical variation in shells of the blackfoot abalone Haliotis iris (Mollusca: Gastropoda: Haliotidae), in southern New Zealand. Pac Sci 58: 47-64

> Gruber N, Hauri C, Zouhair Lachkar Z, Loher D, Frölicher TL, Plattner GK (2012) Rapid progression of ocean acidification in the California Current System. Science 337: 220-223

Hadfield JD (2010) MCMC methods for multi-response generalized linear mixed models: the MCMCglmm R Package. J Stat Softw 33:1-22

Hermans J, Borremans C, Willenz P, André L, Dubois P (2010) Temperature, salinity and growth rate dependences of $\mathrm{Mg} / \mathrm{Ca}$ and $\mathrm{Sr} / \mathrm{Ca}$ ratios of the sea urchin Paracentrotus lividus (Lamarck): an experimental approach. Mar Biol 157:1293-1300

IPCC (Intergovernmental Panel on Climate Change) (2014) Climate change 2014: synthesis report. In: Core Writing Team, Pachauri RK, Meyer LA (eds) Contribution of Working Groups I, II and III to the Fifth Assessment Report of the Intergovernmental Panel on Climate Change. IPCC, Geneva
Killian CE, Metzler RA, Gong Y, Churchill TH and others (2011) Self-sharpening mechanism of the sea urchin tooth. Adv Funct Mater 21:682-690

> Kinjo S, Uehara T, Yazaki I, Shirayama Y, Wada H (2006) Morphological diversity of larval skeletons in the sea urchin family Echinometridae (Echinoidea: Echinodermata). J Mar Biol Assoc UK 86:799-816

Kroeker KJ, Kordas RL, Crim R, Hendriks IE and others (2013) Impacts of ocean acidification on marine organisms: quantifying sensitivities and interaction with warming. Glob Change Biol 19:1884-1896

Kroh A, Mooi R (2011) World Echinoidea Database. www. marinespecies.org/echinoidea (accessed on 28 March 2014)

LaVigne M, Hill TM, Sanford E, Gaylord B and others (2013) The elemental composition of purple sea urchin (Strongylocentrotus purpuratus) calcite and potential effects of $p \mathrm{CO}_{2}$ during early life stages. Biogeosci 10:3465-3477

Lebrato M, McClintock JB, Amsler MO, Ries JB and others (2013) From the Arctic to the Antarctic: the major, minor, and trace elemental composition of echinoderm skeletons. Ecology 94:1434

> Long X, Ma Y, Qi L (2014) Biogenic and synthetic high magnesium calcite-a review. J Struct Biol 185:1-14

> Lunn DJ, Thomas A, Best N, Spiegelhalter D (2000) WinBUGS - a Bayesian modelling framework: concepts, structure, and extensibility. Stat Comput 10:325-337

Ma Y, Aichmayer B, Paris O, Fratzl P and others (2009) The grinding tip of the sea urchin tooth exhibits exquisite control over calcite crystal orientation and Mg distribution. Proc Natl Acad Sci USA 106:6048-6053

Mackenzie FT, Bischoff WD, Bishop FC, Loijens M, Schoonmaker J, Wollast R (1983) Magnesian calcites: lowtemperature occurrence, solubility and solid-solution behavior. In: Reeder RJ (ed) Carbonates: mineralogy and chemistry, Vol 11. Mineralogical Society of America, Washington, p 97-144

Matranga V, Pinsino A, Bonaventura R, Costa C and others (2013) Cellular and molecular bases of biomineralization in sea urchin embryos. Cah Biol Mar 54:467-478

- McClintock JB, Amsler MO, Angus RA, Challener RC and others (2011) The Mg-calcite composition of Antarctic echinoderms: important implications for predicting the impacts of ocean acidification. J Geol 119:457-466

> Morse JW, Andersson AJ, Mackenzie FT (2006) Initial responses of carbonate-rich shelf sediments to rising atmospheric $p \mathrm{CO}_{2}$ and 'ocean acidification': role of high Mg-calcites. Geochim Cosmochim Acta 70:5814-5830

Orr J, Fabry V, Aumont O, Bopp L and others (2005) Anthropogenic ocean acidification over the twenty-first century and its impact on calcifying organisms. Nature 437: $681-686$

Pilkey OH, Hower J (1960) The effect of environment on the concentration of skeletal magnesium and strontium in Dendraster. J Geol 68:203-216

R Development Core Team (2015) R: a language and environment for statistical computing. R Foundation for Statistical Computing, Vienna

Raup DM (1966) The endoskeleton. In: Boolootian RA (ed) Physiology of Echinodermata. John Wiley and Sons Inc, New York, NY, p 379-395

Raven J, Caldeira K, Elderfield H, Hoegh-Guldberg $\mathrm{O}$ and others (2005) Ocean acidification due to increasing atmospheric carbon dioxide. Royal Society Policy Document 12/05. The Royal Society, London 
Richter DK, Bruckschen P (1998) Geochemistry of recent tests of Echinocyamus pusillus: constraints for temperature and salinity. Carbonates Evaporites 13:157-167

Ries JB (2004) Effect of ambient Mg/Ca ratio on Mg fractionation in calcareous marine invertebrates: a record of the oceanic $\mathrm{Mg} / \mathrm{Ca}$ ratio over the Phanerozoic. Geology 32: 981-984

Ries JB (2010) Review: geological and experimental evidence for secular variation in seawater $\mathrm{Mg} / \mathrm{Ca}$ (calcitearagonite seas) and its effects on marine biological calcification. Biogeosciences 7:2795-2849

Ries JB (2011) Skeletal mineralogy in a high- $\mathrm{CO}_{2}$ world. J Exp Mar Biol Ecol 403:54-64

Sewell MA, Hofmann GE (2011) Antarctic echinoids and climate change: a major impact on the brooding forms. Glob Change Biol 17:734-744

Smith AB (1980) Biomineralization in echinoderms. In: Carter JG (ed) Skeletal biomineralization: patterns, processes and evolutionary trends. Short Courses in Geology, Vol 5. American Geophysical Union, p 117-147

Smith AB (1984) Echinoid palaeobiology. George Allen and Unwin, London

Smith AB, Kroh A (eds) (2011) The echinoid directory. Available at www.nhm.ac.uk/research-curation/projects/ echinoid-directory/ (accessed 10 Feb 2015)

Smith AB, Pisani D, Mackenzie-Dodds JA, Stockley B, Webster BL, Littlewood DTJ (2006) Testing the molecular clock: molecular and paleontological estimates of divergence times in the Echinoidea (Echinodermata). Mol Biol Evol 23:1832-1851

Smith AM, Key MM Jr, Gordon DP (2006) Skeletal mineralogy of bryozoans: taxonomic and temporal patterns. Earth Sci Rev 78:287-306

Smith AM, Berman J, Key MM Jr, Winter DJ (2013) Not all sponges will thrive in a high- $\mathrm{CO}_{2}$ ocean: review of the mineralogy of calcifying sponges. Palaeogeogr Palaeo-

Editorial responsibility: James McClintock,

Birmingham, Alabama, USA climatol Palaeoecol 392:463-472

Steneck RS (2013) Sea urchins as drivers of shallow water benthic community structure. In: Lawrence J (ed) Sea urchins: biology and ecology. Academic Press, San Diego, CA, p 195-212

Stock SR (2014) Sea urchins have teeth? A review of their microstructure, biomineralization, development and mechanical properties. Connect Tissue Res 55:41-51

- Stumpp M, Hu MY, Melzner F, Gutowska MA and others (2012) Acidified seawater impacts sea urchin larval pH regulatory systems relevant for calcification. Proc Natl Acad Sci USA 109:18192-18197

Sumich JL, McCauley JE (1972) Calcium-magnesium ratios in the test plates of Allocentrotus fragilis. Mar Chem 1: 55-59

Uthicke S, Ebert T, Liddy M, Johansson C, Fabricius KA, Lamare M (2016) Echinometra sea urchins acclimatized to elevated $p \mathrm{CO}_{2}$ at volcanic vents outperform those under present-day $\mathrm{vCO}_{2}$ conditions. Glob Change Biol 22:2451-2461

Walter LM, Morse JW (1984) Magnesian calcite stabilities: a re-evaluation. Geochim Cosmochim Acta 49:1503-1513

- Wang RZ, Addadi L, Weiner S (1997) Design strategies of sea urchin teeth: structure, composition and micromechanical relations to function. Philos Trans R Soc Lond B Biol Sci 352:469-480

- Weber JN (1969) The incorporation of magnesium into the skeletal calcites of echinoderms. Am J Sci 267: $537-566$

- Wilt FH (1999) Matrix and mineral in the sea urchin larval skeleton. J Struct Biol 126:216-226

Wolfe K, Dworjanyn S, Byrne M (2013) Effects of ocean warming and acidification on survival, growth and skeletal development in the early benthic juvenile sea urchin (Heliocidaris erythrogramma). Glob Change Biol 19:2698-2707

Submitted: July 14, 2016; Accepted: September 26, 2016

Proofs received from author(s): November 22, 2016 